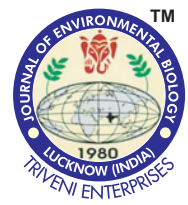

\title{
Biosorption of chromium from aqueous solution by Chaetomorpha antennina
}

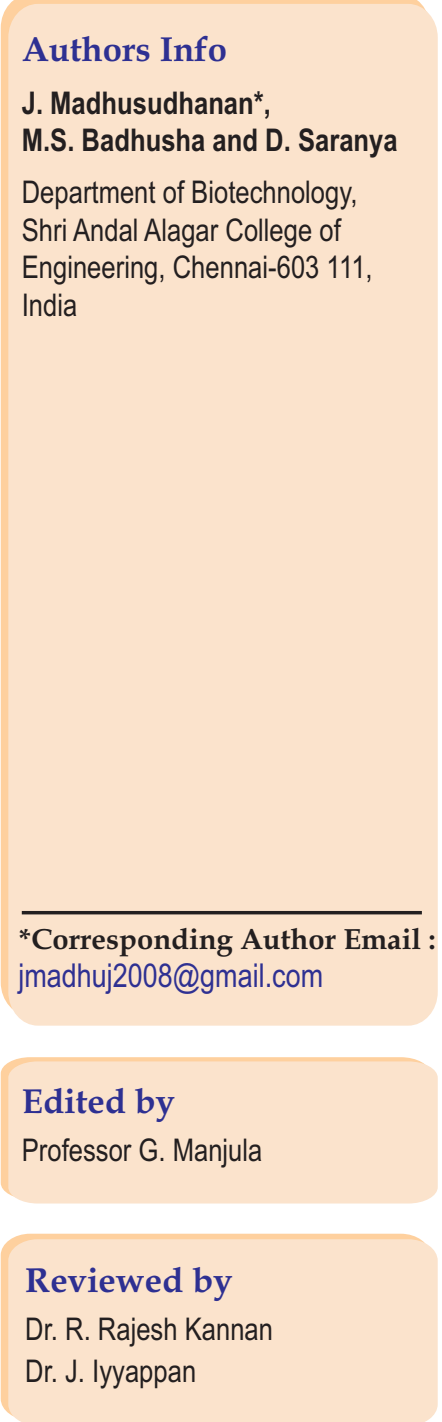

\begin{abstract}
Aim: Aquatic system poses a serious threat from industrial effluents having heavy metals and chromium due to its wide use in industry. It becomes a prime responsibility for removal of chromium ions from effluents before discharged into the aquatic body. Biosorption comes as an effective technology in the removal of heavy metals from industrial effluents. This study deals with biosorption of chromium from aqueous solution by Chaetomorpha antennina.
\end{abstract}

Methodology: Biosorption of chromium was studied using microalgae Chaetomorpha antennina, as an adsorbent, which was characterized using Fourier Transform Infrared (FTIR) and Scanning Electron Microscope (SEM) to determine the functional groups and the structural characteristics, respectively. Equilibrium and optimization studies for various parameters like $\mathrm{pH}(1-11)$, adsorbent dosage $\left(0.2-1 \mathrm{~g} \mathrm{l}^{-1}\right)$, initial chromium concentration ( $\left.10 \mu \mathrm{g}-100 \mu \mathrm{g} \mathrm{m}^{-1}\right)$ and agitation time $(0-50 \mathrm{mins})$ were examined using batch process.

Results: The maximum percent removal of chromium ions was found to be $83 \%$ at $\mathrm{pH} 1$ at an adsorbent dosage of $1 \mathrm{~g}$ at a contact time of $30 \mathrm{~min}$, which showed maximum adsorption.

Interpretation: Biosorption of chromium ions onto the surface of Chaetomorpha antennina, showed that biosorption was dependent on the equilibrium $\mathrm{pH}$ of the solution, biosorbent and contact time.

Key words: Biosorption, Chaetomorpha antennina, Chromium, Industrial effluent.

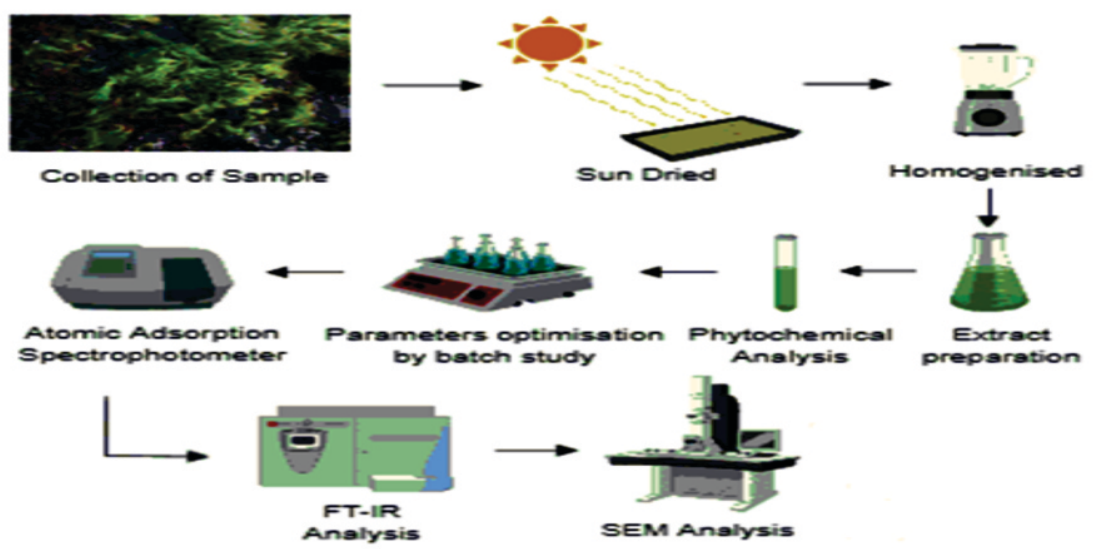

How to cite : Madhusudhanan, J., M.S. Badhusha and D. Saranya: Biosorption of chromium from aqueous solution by Chaetomorpha antennina. J. Environ. Biol., 40,742-747 (2019). DOI: http://doi.org/10.22438/jeb/40/4(SI)/JEB_03 


\section{Introduction}

Presence of heavy metals in the aquatic system has become the most pervasive threat to the environment. In the age of unplanned industrialization and urbanization, discharge of nontreated industrial effluent into the water bodies is impending dangerous towards human health and aquatic environment due to the presence of toxic heavy metals (Gupta et al., 2001).

The concern regarding heavy metals is toxicity and their persistence in bioaccumulating in living organisms. Chromium is one of the widely used metal and finds its application in stainless steel production, chromate preparation and textile industries. Chromium is a patent water pollutant, which exits in two forms: hexavalent and trivalent. (Rezaei, 2016; Vijayaraghavan et al., 2008). A trivalent form of chromium ( $\mathrm{Cr}$ III ion) is an essential trace element found in insulin and lipid metabolism (Vincent, 2017), but still it is debated issue owing to its toxicity (Jaishankar et al., 2014; Zhitkovich 2005). Another form is hexavalent, which is a potent causes pollutant than $\mathrm{Cr} I \mathrm{II}$ and causes cancer, diarrhea, hemorrhage (Gurkan et al., 2017). It is considered as one of the hazardous substance as per Agency for Toxic Substance and Disease Registry (ATSDR)

There are various methods reported by Owlad et al. (2009) for removal of metal ions exchange, chemical precipitation, activated carbon (Kobya et al., 2005), reverse osmosis and adsorption. Among the reported methods bio-adsorption comes as a versatile and efficient method in the removal of metal ions which overcomes the costly methods as chemical precipitation where a huge amount of chemical required to remove the metal ions and activated carbon which comes as a costly adsorbent.

Biosorption of heavy metals has gained interest as an alternative method for activated carbon. A wide range of studies done on biosorption (Veglio and Beolchini 1997) using Spirulina (Rezaei, 2016), Saccharomyces cerevisiae (Wang et al., 2006), brown seed algae (Yun et al., 2011), Rhizopus nigricans (Bai and Abraham 2001), Chitosan based biosorbent (Wang and Chan 2014), Bacillus thurigiensis (Oves et al., 2013), Chaetomorpha antennina (Lahari et al., 2011), Aspergillus niger (Khambhaty et al., 2009) have been reported. The process of biosorption depends upon various parameters like $\mathrm{pH}$, temperature, type of biosorbent material used, contact time and material dosage (Farooq et al., 2010; Volesky and Holan, 1995).

There are very few reports available on biosorption properties of microalgae, Chaetomorpha antennina and this is the first report on biosorption of $\mathrm{Cr} \mathrm{VI}$ using Chaetomorpha antennina. In view of the above, this study was conducted to evaluate properties of Chaetomorpha antennina as a potential adsorbent and optimization of various parameters in removal of $\mathrm{CrVl}$ from an aqueous solution of industrial effluents.

\section{Materials and Methods}

Chaetomorpha antennina - Biosorbent: Chaetomorpha antennina is a green algae belonging to family Cladophoraceace.
The seaweeds were collected from the Ennore Beach, Chennai. Identification of collected sample was done at Madras University. The sample was thoroughly washed with water for removing dirt and then sun dried for 3 days, and thoroughly grinded into powder the powder was stored in an air-tight container and no extra chemical treatment was required.

Stock solution: About $100 \mathrm{mg}$ of potassium dichromate (Bio Rad) was dissolved in $100 \mathrm{ml}$ of deionized water for preparation of the stock solution, which was further diluted for experiments as per required concentrations. Different $\mathrm{pH}$ values for the experiment were obtained by using $1 \mathrm{~N} \mathrm{HCl} / 1 \mathrm{~N} \mathrm{NaOH}$.

Batch process and optimization: Dilution of stock solution was done to obtain different concentrations $(10-100 \mu \mathrm{g} \mathrm{ml})$ of standard test solution ( $\mathrm{Cr} \mathrm{VI})$. Batch process was carried out using $250 \mathrm{ml}$ of flask containing $50 \mathrm{ml}$ of standard test solution at an agitation speed of $150 \mathrm{rpm}$ in orbital shaker and biosorbent was added with desired quantity $(0.2-1 \mathrm{~g})$. To obtain the optimum parameters for biosorption process, an experimental study was done by varying one parameter at a time while keeping another parameter constant and this method was followed to obtain each optimum parameter.

Test solution was measured at different time interval to find the residual concentration of chromium ions until the reaction reached an equilibrium point. Using Whatmann filter paper, biosorbent was filtered after which it was centrifuged at $7000 \mathrm{rpm}$ for $10 \mathrm{~min}$ and the filtrate was measured using atomic absorption spectroscopy to analyze the chromium concentration. Under similar conditions, blank studies were carried out.

Characterization studies : The adsorbent was characterized before and after treatment using FTIR and SEM to study the functional sites and surface topography.

\section{Results and Discussion}

Phytochemical Analysis: Phytochemical analysis of Chaetomorpha antennina showed the presence of carbohydrates, alkaloids, quinones, triterpenoids, coumarins and flavonoids (Thanigaivel et al., 2014; Subathraa and Poonguzhali, 2013).

Biosorption is a surface phenomenon where $\mathrm{pH}$ acts an important parameter in binding of ionic form heavy metals onto the surface of adsorbent (Mishra et al., 2015). The experimental study was carried out to find the optimal $\mathrm{pH}$ for removal of chromium $\mathrm{VI}(\mathrm{Cr}(\mathrm{VI}))$ ions from aqueous solution. Mahajan et al. (2011) suggested that precipitation of $\mathrm{Cr}(\mathrm{VI})$ ions occur at higher $\mathrm{pH}$ due to negative charge on the overall surface of biosorbent decreases the biosorption of Crions.

The results depicted in Fig. $1 \mathrm{~A}$ gives a clear information that $\mathrm{Cr}(\mathrm{VI})$ ions were adsorbed at lower $\mathrm{pH}$ 1-3 and adsorption decreased as the $\mathrm{pH}$ range increased. Optimum $\mathrm{pH}$ was found to 

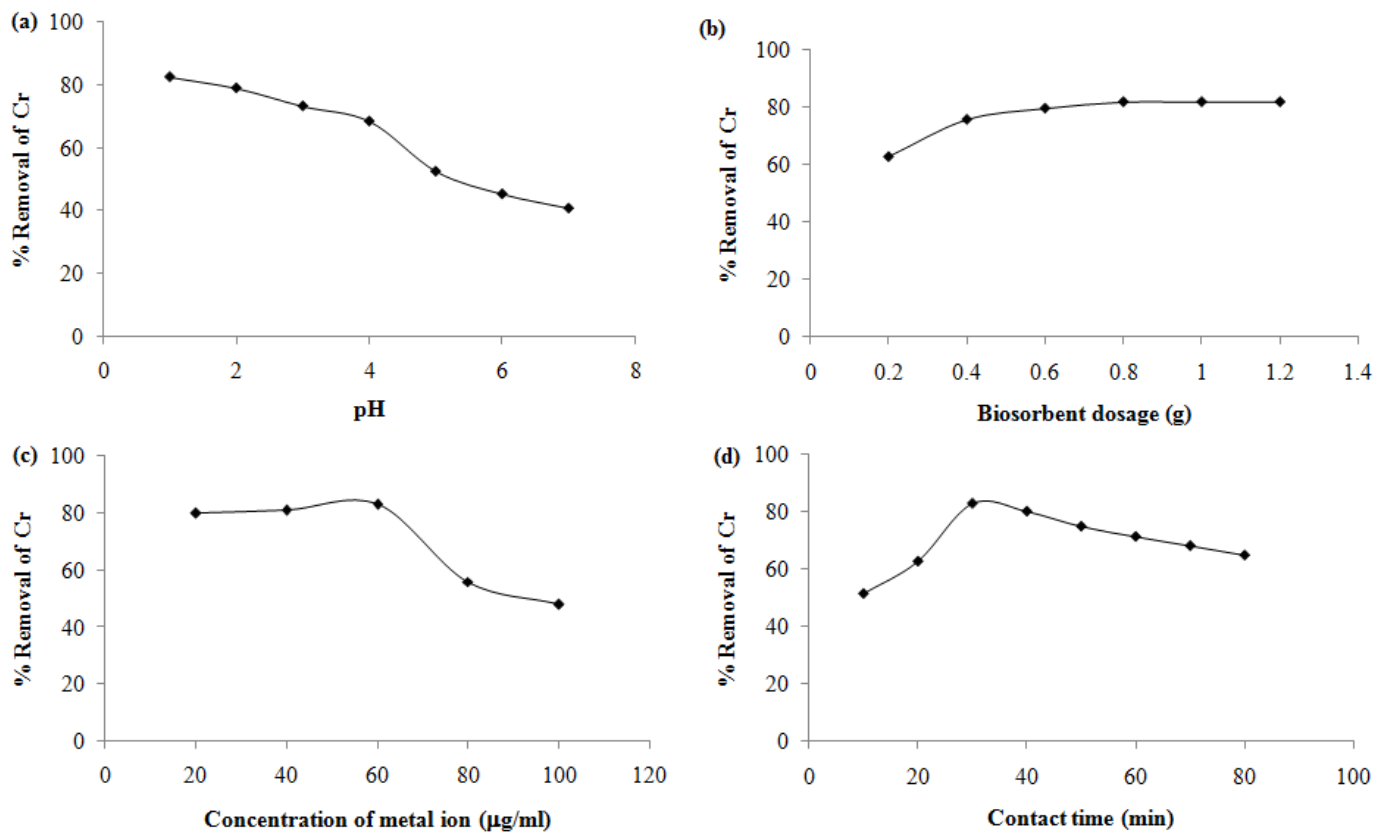

Fig. 1: Effect of $(A)$ varying $\mathrm{pH}$; $(\mathrm{B})$ biosorbent dosage; $(\mathrm{C})$ various concentration of metal ion and (D) different contact time on the percentage removal of chromium.
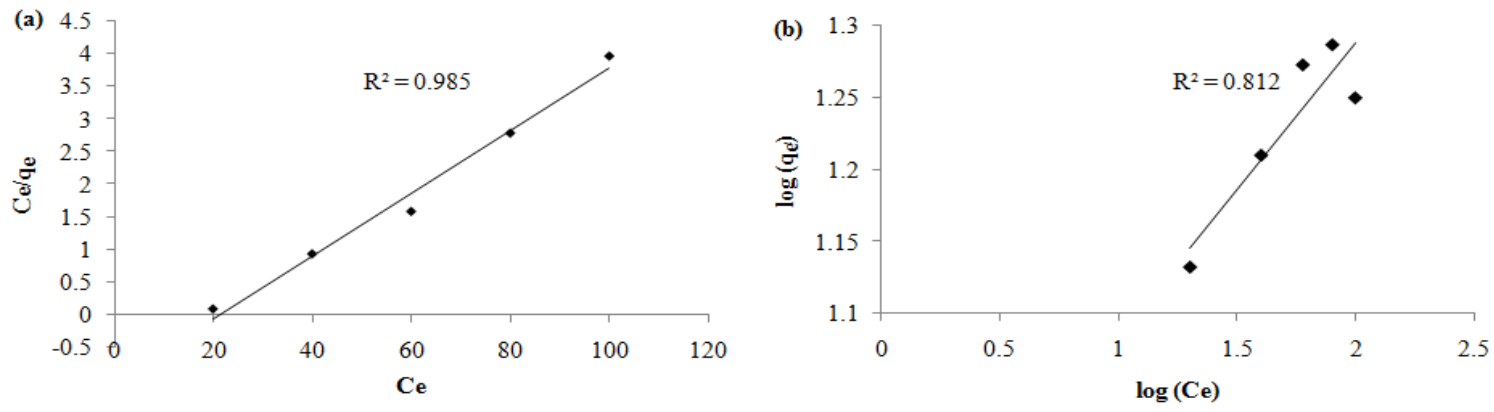

Fig. 2 : Equilibrium Modeling: (A) Langmuir isotherm; (B) Freundlich isotherm.
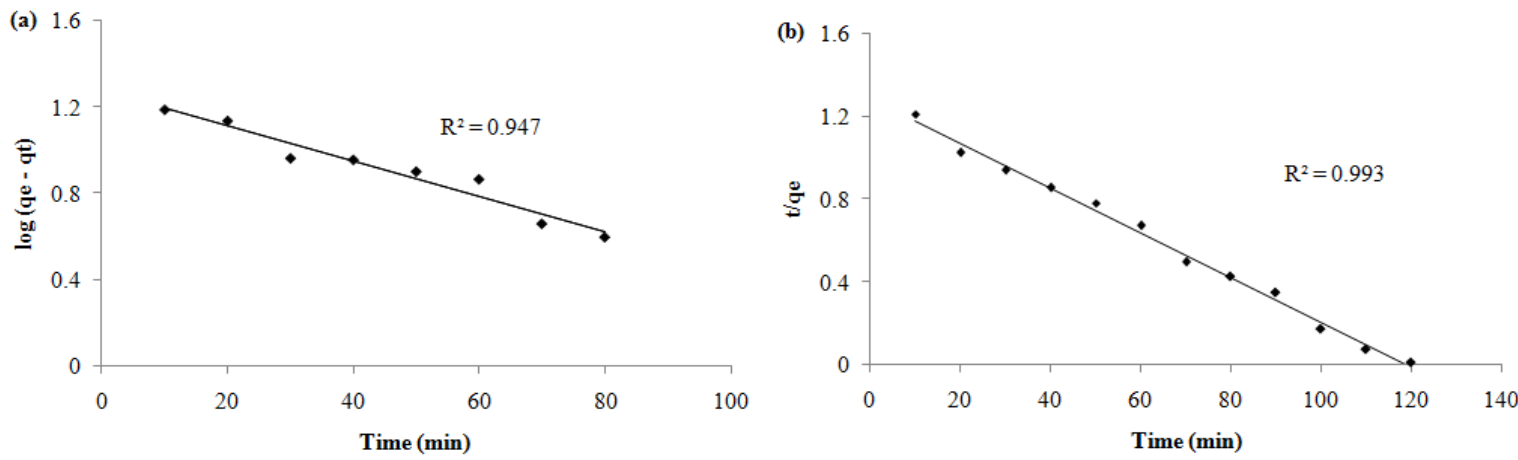

Fig. 3: Kinetic models: (A) Pseudo-first order kinetics; (B) Pseudo-first order kinetics. 

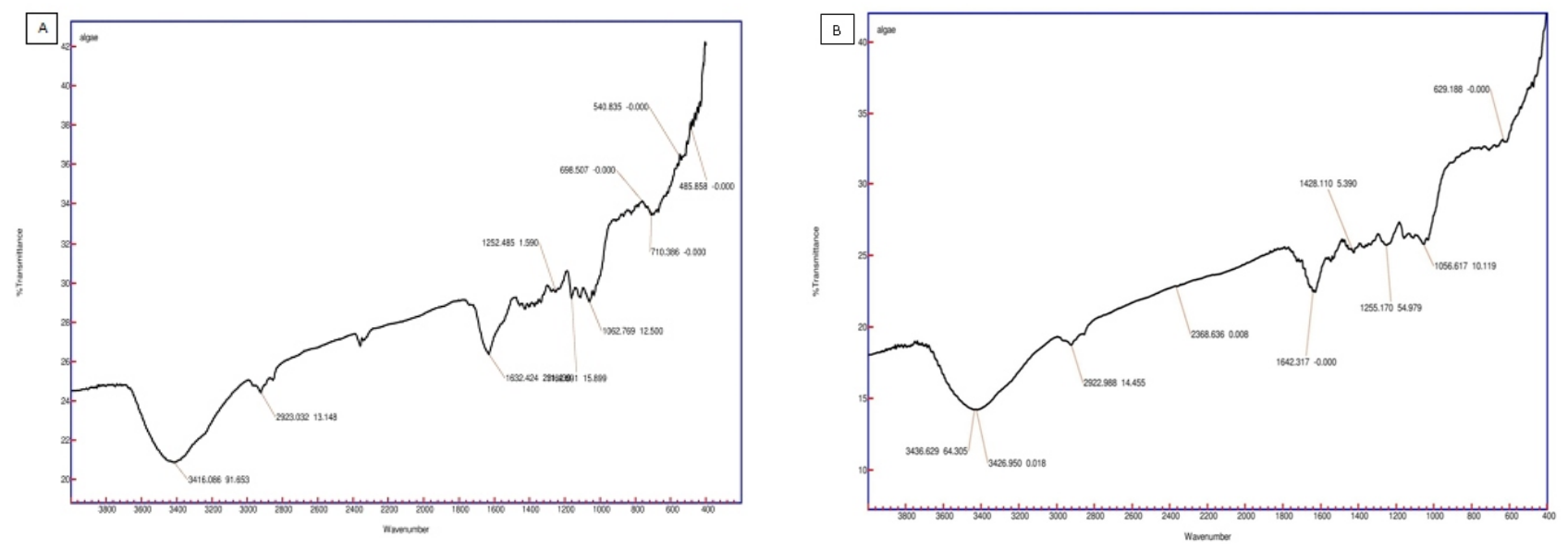

Fig. 4 : (A) FTIR analysis before treatment; (B) FTIR analysis after treatment.
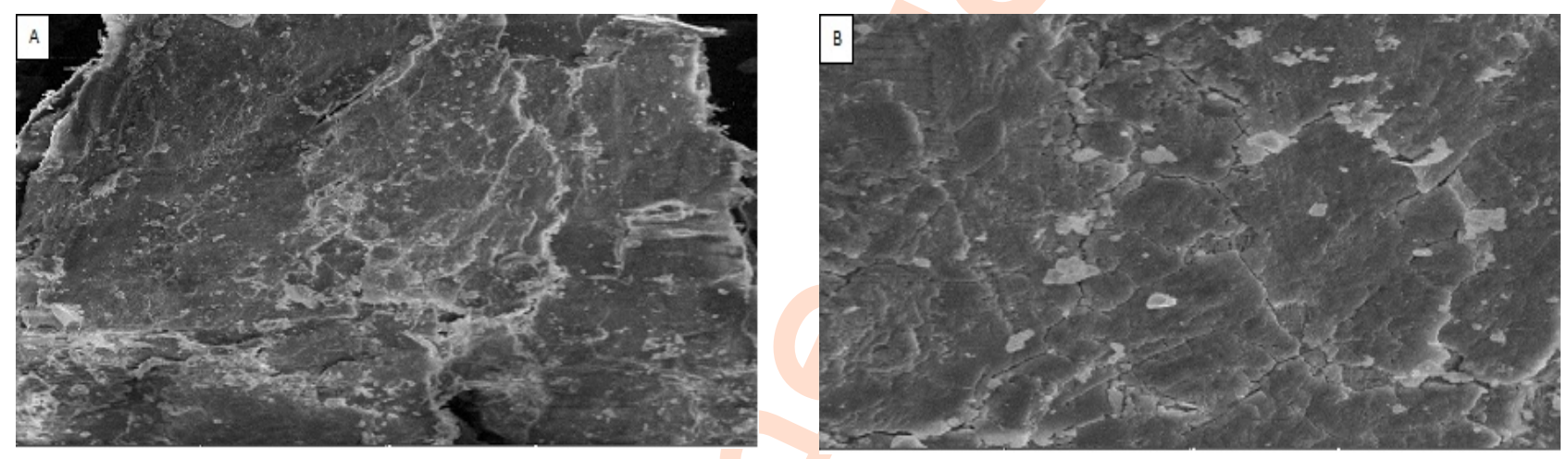

Fig. 5 : (A) Scanning Electron Microscope image at 501x magnification before adsorption; (B) Scanning Electron Microscope image at 2.49x magnification before adsorption.
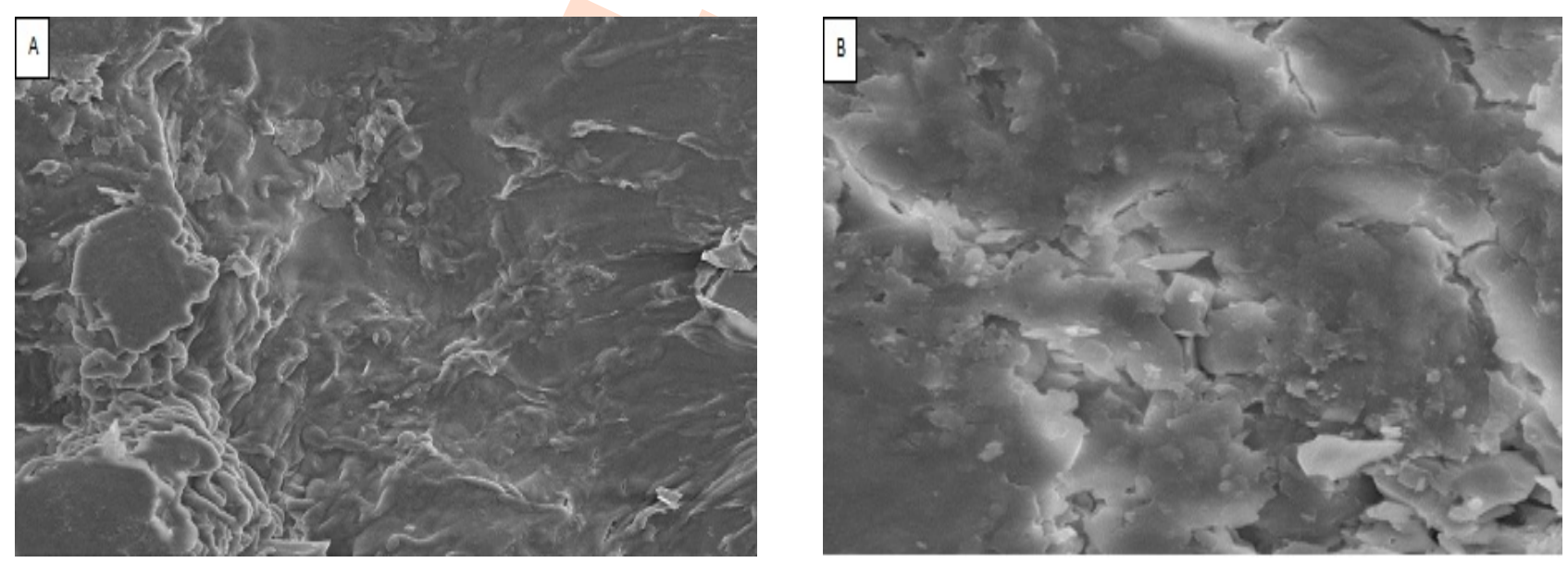

Fig. 6: (A) Scanning Electron Microscope result after adsorption at magnification level of $1 \mathrm{kx}$; (B) Scanning Electron Microscope result for after adsorption at magnification level of $5 \mathrm{kx}$. 
be at 1 and was used as the optimum value for further experimental studies. The chemistry behind the positively charged surface of biosorbent is due to protonation occurring at lower $\mathrm{pH}$ values, which makes easy binding of $\mathrm{Cr}(\mathrm{VI})$ anions to surface functional groups of biosorbent, and biosorption increases at lower $\mathrm{pH}$ due to higher protonation on the surface of biosorbent.

Biosorption of $\mathrm{Cr}(\mathrm{VI})$ decreases as $\mathrm{pH}$ value increases, due to decrease in the hydrogen ion concentration. As a result, chromium ions with a negative charge are prevented from binding to biosorbent having negatively charged surface, with that biosorption decreases (Pehlivan et al., 2012).

Effect of biosorbent dosage experiment was carried out at varying dosages $(0.2-1 \mathrm{~g})$ at optimum values which were already carried out with chromium concentration of $60 \mathrm{\mu g} \mathrm{m}^{-1}$. Results shown in Fig. 1B indicate that biosorption of $\mathrm{Cr}(\mathrm{VI})$ increased at higher concentration and it was found out that 0.8 and $1 \mathrm{~g}$ values showed better biosorption rate upto $82 \%$.

The effect of different metal ion concentration was conducted at varying concentration from $20-100 \mu \mathrm{g} \mathrm{ml}^{-1}$. As shown in figure (Fig. $1 \mathrm{C}$ ) the biosorption increased at lower concentration like $20 \mu \mathrm{g} \mathrm{ml}^{-1}, 40 \mathrm{\mu g} \mathrm{ml}^{-1}$ and $60 \mathrm{\mu g} \mathrm{ml}^{-1}$. Metal ions increased concentration have greater chances to collide with functional sites present on biosorbent giving the $\mathrm{Cr}(\mathrm{VI})$ required thrust to overcome the resistant between the aqueous phase and solid phase during the mass transfer (Baral et al., 2006).

Effect of contact time (Fig. 1D) was carried out in the range of 10-100 min. Initially there was a rapid increase in adsorption which decreases after 60 minutes due to unavailability of active sites.

After biosorbent dosage, $\mathrm{pH}$ and initial concentration were optimized, a study was conducted to correlate the results observed in a forementioned parameters. About $83 \%$ removal of $\mathrm{Cr}$ ions were removed at a $\mathrm{pH}$ of 1 , concentration of $60 \mathrm{\mu g} \mathrm{ml}^{-1}$, bioadsorbent dosage of $0.8 \mathrm{~g}$ and contact time of $30 \mathrm{~min}$.

The Langmuir isotherm can be represents as follows:

$$
1 / q_{e}=1 / Q_{0}+1 / Q_{0} K_{L} C_{e}
$$

Where qe is the amount of metal adsorbed per gram of the adsorbate at equilibrium $\left(\mathrm{mg} \mathrm{g}^{-1}\right), Q_{0}$ is the maximum monolayer coverage capacity $\left(\mathrm{mg} \mathrm{g}^{-1}\right), \mathrm{K}_{\mathrm{L}}$ is the Langmuir isotherm constants (I $\mathrm{mg}^{-1}$ ) and $\mathrm{C}_{\mathrm{e}}$ is the equilibrium concentration of the adsorbate $\left(\mathrm{mgl}^{-1}\right)$. The values of $Q_{0}$ and $K_{L}$ were computed from the slopes and intercepts of Langmuir plot of $1 / q_{e} V s 1 / C_{e}$ as shown in Fig. $2 A$.

Freundlich adsorption isotherm is tested to check the affinity between adsorbate and adsorbent. The linearized equation of Freundlich isotherm is represented as:

$$
\log q e=\log K f+1 / n \log C e
$$

where, $\mathrm{Kf}$ is the Freundlich isotherm $\left(\mathrm{mg} \mathrm{g}^{-1}\right), \mathrm{n}$ is the adsorption intensity, $\mathrm{C}_{\mathrm{e}}$ is the equilibrium concentration of the adsorbate $\left(\mathrm{mg} \mathrm{l}^{-1}\right)$, qe is the amount of metal adsorbed per gram of adsorbate at equilibrium $\left(\mathrm{mg} \mathrm{g}^{-1}\right)$. The constant $\mathrm{K}_{\mathrm{f}}$ is an indicator of adsorption capacity, while $1 / \mathrm{n}$ is a function of strength of adsorption in adsorption process which was found by linear plot as shown in (Fig. 2B)

The slightly higher in $R_{2}$ value for Langmuir compared with Freundlich isotherm models indicated the perfect fit of Langmuir isotherm model.

The kinetics mechanism involved in $\mathrm{Cr}(\mathrm{VI})$ ion adsorption was investigated using kinetic models such as first-order and pseudo second-order. The model with relatively higher $R_{2}$ values describes the kinetics of $\mathrm{Cr}(\mathrm{VI})$ ion adsorption successfully. Firstly, the simple first-order rate kinetics given as follows:

$$
\log C_{e}=k_{1} / 2.303 t+\log C_{0}
$$

where, $\mathrm{C}_{0}$ and $\mathrm{C}_{\mathrm{e}}$ are the concentration of metal ion at initial and at time $t\left(\mathrm{mgl}^{-1}\right)$ respectively, and $\mathrm{k}_{1}$ is the first order rate constant (1/min). (Fig. $3 A$ ) depicts the plot of $\log C_{e}$ vs. $t$ for constant initial concentration of metal ions from which the rate constant and correlation coefficient were obtained. The deviation in theoretical data indicates the failure in expressing the adsorption process by the simple first order kinetics. The pseudosecond order kinetics was determined as follows:

$$
t / q_{e}=1 / k_{2} q_{0}^{2}+t / q_{0}
$$

Where, $\mathrm{k}_{2}$ is the rate constant of second order adsorption ( $\mathrm{g} / \mathrm{mg} \mathrm{min}$ ). The plot of t/qe against $\mathrm{t}$ (Fig. 3B) is a linear fit and also on comparison, highest $R_{2}$ value of 0.993 was observed which jointly suggests the applicability of this kinetic model for the system. It can be confirmed that the $\mathrm{Cr}(\mathrm{VI})$ ion adsorption process follows the pseudo-second order kinetics.

Fourier Transform Infrared spectroscopy revealed functional sites like hydroxyl, carbonyl, carboxyl, amine, amide and ether groups present on biosorbent before and after treatment. Presence of carboxylic group was confirmed by $\mathrm{OH}$ and carbonyl groups present at around $3400 \mathrm{~cm}^{-1}$ and $1600 \mathrm{~cm}^{-1}$. Biosorption was assumed to take place due to smaller shift in the range of peak indicating the involvement of $\mathrm{NH}, \mathrm{OH}, \mathrm{C}=\mathrm{O}$ groups towards the binding of metal ions in aqueous solution.

Biosorption process was found to be dependent on certain parameters like $\mathrm{pH}$, adsorbent dosage, initial concentration and contact time. Maximum removal of chromium ions occurred at the $\mathrm{pH} 1$ due to protonation of anionic $\mathrm{Cr}(\mathrm{VI})$ ions onto the surface functional sites of biosorbent resulted in better adsorption by Chaetomorpha antennina (Mishra et al., 2015). Initial concentration was a factor for the time taken by biosorbent for adsorption of $\mathrm{Cr}(\mathrm{VI})$ ions. Similarly, the adsorption rate decreased as initial concentration increased. After optimal 
parameters were found, $83 \%$ of chromium ions were removed at $\mathrm{pH} 1$ with a contact time of $30 \mathrm{~min}$ having $60 \mathrm{\mu g} \mathrm{ml}^{-1}$ as the initial concentration. Characterization studies like FTIR revealed certain functional groups like hydroxyl, amine, amide, carboxyl and carbonyl groups present on biosorbent which were assumed to be responsible for biosorption. SEM images before and after biosorption showed the clear image of metal uptake by the Chaetomorpha antennina. The experimental results obtained from the batch process studies of green algae Chaetomorpha antennina provided fundamental information about the biosorption properties of Chaetomorpha antennina sp., and can be used as efficient and eco-friendly biosorbent.

\section{References}

Anitha, T., P.S. Kumar, K.S. Kumar, B. Ramkumar and S. Ramalingam: Adsorptive removal of $\mathrm{Pb}$ (II) ions from polluted water by newly synthesized chitosan-polyacrylonitrile blend: Equilibrium, kinetic, mechanism and thermodynamic approach. Proc. Saf. Environ. Protec., 98, 187-197(2015).

Bai, R.S. and T.E. Abraham: Biosorption of $\mathrm{Cr}$ (VI) from Aqueous Solution by Rhizopus nigricans. Bioresource Technology, 79, 73-81 (2001).

Baral, S.S., N.S. Dasa and P. Rath: Hexavalent chromium removal from Aqueous Solution by Adsorption on Treated Sawdust. Biochem. Eng. J., 31, 216-222 (2006).

Farooq, U., J.A. Kozinski, M.A. Khan and M. Athar: Biosorption of heavy metal lons using wheat based biosorbents - A review of the recent literature. Biores. Technol., 101, 5043-5053 (2010).

Gupta, V.K., A.K. Shrivastava and N. Jain: Biosorption of Chromium (VI) from aqueous solutions by green algae spirogyra species. Wat. Res., 35, 4079-4085 (2001).

Gurkan, R., H.I. Ulusoy and M. Akcay: Simultaneous determination of dissolved inorganic chromium species in waste water/natural waters by surfactant sensitized catalytic kinetic spectrophotometry. Arab. J. Chem., 10, S450-S460 (2017).

Jaishankar, M., T. Tseten, N. Anbalagan, B.B. Mathew and K.N. Beeregowda: Toxicity, mechanism and health effects of some heavy metals. Int. Toxicol., 7, 60-72 (2014).

Khambhaty, Y., K. Mody, S. Basha and B. Jha: Biosorption of $\mathrm{Cr}(\mathrm{VI})$ onto marine aspergillus niger: Experimental studies and pseudosecond order kinetics. World J. Microbiol. Biotechnol., 25, 1413-1421(2009).

Kobya, M., E. Demirbas, E. Senturk and M. Ince: Adsorption of heavy metal ions from aqueous solutions by activated carbon prepared from apricot stone. Biores. Technol., 96, 1518-1521 (2005).

Lahari, S.B., P. King and V.S.R.K. Prasad: Biosorption of copper from aqueous solution by Chaetomorpha antennina Algae Biomass. Iran. J. Environ. Health. Sci. Eng., 8, 353-362 (2011).
Mahajan, G. and D. Sud: Kinetics and equilibrium studies on $\mathrm{Cr}$ (VI) metal ions remediation by arachis hypogea shells: A green approach. Bio. Resour., 6, 3324-3338 (2011).

Mishra, A., A. Dubey and S. Shinghal: Biosorption of chromium (VI) from aqueous solutions using waste plant biomass: Int. J. Environ. Sci. Technol.,12, 1415-1426 (2015).

Oves, M., M.S. Khan and A. Zaidi: Biosorption of heavy metals by bacillus thuringiensis strain OSM29 originating from industrial effluent contaminated north indian soil. Saudi J. Biolog. Sci., 20, 121-129 (2013).

Owlad, M., M.K. Aroua, W.A.W. Daud and S. Baroutian: Removal of hexavalent chromium-contaminated water and wastewater: A review. Water, Air and Soil Poll., 200, 59-77 (2009).

Pehlivan, E., E. Pehlivan and H.T. Kahraman: Hexavalent chromium removal by Osage Orange. Food Chemistry, 133, 1478-1484 (2012).

Rezaei, H.: Biosorption of chromium by using Spirulina sp. Arab. J. Chem., 9, 846-853 (2016).

Sang, Y.Y., D. Park, J.M. Park and B. Volesky: Biosorption of trivalent chromium on the brown seaweed biomass. Environ. Sci. Technol., 35, 4353-4358 (2011)

Seenuvasan, M., J. R. G. Suganthi, G. Sarojini, G. C. G. Malar, M. E. Priya, M. A. Kumar: Effective utilization of crustacean shells for preparing chitosan composite beads: Applications in ameliorating the biosorption of an endocrine disrupting heavymetal. Desalination and Water Treatment, 121, 28-35 (2018).

Subathraa, K. and T.V. Poonguzhali: Effect of Different Extracts of Chaetomorpha Antennina and their Phytochemical Screening. Int. J. Curr. Sci., 6, 35-39 (2013).

Thanigaivel, S., S.V. Kumar, A. Mukherjee, N. Chandrasekaran and J. Thomas: Antioxidant and antibacterial activity of Chaetomorpha antennina against shrimp pathogen vibrio parahaemolyticus. Aquaculture, 433, 467-475 (2014).

Vincent, B.J.: New Evidence against Chromium as an Essential Trace Element. J. Nutr., 147, 2212-2219 (2017).

Volesky, B. and Z.R. Holan: Biosorption of heavy metals. Biotechnol. Prog., 11, 235-250 (1995).

Veglio, F. and F. Beolchini: Removal of metals by biosorption: A review. Hydrometallurgy, 44, 301-316 (1997).

Vijayaraghavan, K. and Y.S. Yun: Bacterial biosorbents and biosorption. Biotechnol. Adv., 26, 266-291 (2008).

Wang, J. and C. Chen: Chitosan-based Biosorbents: Modification and application for biosorption of heavy metals and radionuclides. Biores. Technol., 160,129-141 (2014).

Wang, J. and C. Chen: Biosorption of heavy metals by Saccharomyces cerevisiae:Areview. Biotechnol. Adv., 24, 427-451 (2006)

Zhitkovich, A.: Importance of chromium-DNA adducts in mutagenicity and toxicity of chromium (VI). Chem. Res. Toxicol., 18, 3-11 (2005). 